\title{
Penerapan dan Evaluasi PSAP Nomor 13 dalam Penyajian Laporan Keuangan (Studi pada Universitas Pendidikan Ganesha)
}

\section{A.A. Sagung Intan Kesuma Dewi ${ }^{1}$ \\ Fakultas Ekonomi dan Bisnis \\ Universitas Udayana, Indonesia}

\author{
Ketut Muliartha ${ }^{2}$ \\ Fakultas Ekonomi dan Bisnis \\ Universitas Udayana, Indonesia
}

\begin{abstract}
Surel : intankusuma10@gmail.com
\section{ABSTRAK}

Penelitian ini dilakukan dengan tujuan untuk mengetahui dan mengevaluasi penerapan PSAP Nomor 13 dalam penyajian laporan keuangan Universitas Pendidikan Ganesha. Penelitian ini menggunakan metode kualitatif dengan pendekatan yang digunakan adalah pendekatan studi kasus. Data diperoleh melalui dokumentasi, observasi, serta wawancara mendalam. Hasil dalam penelitian menunjukkan bahwa Universitas Pendidikan Ganesha telah mengacu pada PSAP Nomor 13. Beberapa kendala yang ditemukan dalam penyusunan laporan keuangan yakni, 1) pemahaman SDM dalam penggunaan basis akuntansi akrual secara penuh masih belum menyeluruh dan 2) penggunaan sistem desentralisasi dalam pengelolaan keuangan membuat adanya bias informasi dalam pelaporan keuangan.
\end{abstract}

Kata Kunci: PSAP Nomor Layanan Umum 13; Laporan Keuangan; Badan Layanan Umum.

\section{Implementation and Evaluation of PSAP Number 13 in Presentation of Financial Statements (Study at Ganesha University of Education)}

\section{ABSTRACT}

This research was conducted with the aim of knowing and evaluating the application of PSAP Number 13 in presenting the financial statements of Universitas Pendidikan Ganesha. This research uses qualitative methods with the approach used is a case study approach. Data obtained through documentation, observation, and in-depth interviews. The results in this study indicate that Universitas Pendidikan Ganesha has referred to PSAP Number 13. There are several obstacles found in the preparation of the financial statements which are, 1) the understanding of human resources in the use of the accrual basis is not yet comprehensive 2) the used of decentralized system in financial management creates an biased information.

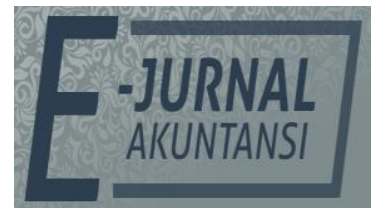

e-ISSN 2302-8556

Vol. 31 No. 2

Denpasar, Februari 2021

Hal. 288-297

DOI:

10.24843/EJA.2021.v31.i02.p02

PENGUTIPAN:

Dewi, A.A.S.I.K., \&

Muliartha, K (2021).

Penerapan dan Evaluasi PSAP Nomor 13 dalam

Penyajian Laporan

Keuangan (Studi pada

Universitas Pendidikan Ganesha). E-Jurnal Akuntansi,

31(2), 288-297

RIWAYAT ARTIKEL:

Artikel Masuk:

14 Mei 2020

Artikel Diterima:

7 Februari 2021

Keywords: $\quad$ PSAP Number 13; Financial Reports; Public Service Agency.

Artikel dapat diakses : https://ojs.unud.ac.id/index.php/Akuntansi/index 


\section{PENDAHULUAN}

Reformasi dalam suatu negara timbul karena tuntutan masyarakat kepada pemerintah untuk menciptakan lingkungan pemerintahan yang baik, efektif, efisien, dan taat hukum (Hajar 2015). Nilai inovasi pada sektor publik mendorong berbagai pemerintahan untuk mengimplementasikan layanan publik yang lebih baik (Pratama 2020). OECD (Organization for Economics Cooperation and Developments) menyatakan bahwa pemerintahan yang baik akan memotivasi program dan agenda pemerintah yang berorientasi pada masyarakat (Wicaksana et al. 2019). Agenda reformasi pada sektor publik ditandai dengan munculnya konsep New Public Management pada tahun 1991 yang diperkenalkan oleh Christopher Hood dengan anjuran pemerintah untuk meninggalkan paradigma lama yang cenderung pada birokratis yang gemuk serta tidak efisien dan tidak efektif dalam pemberian pelayanan. Paradigma baru yang diperkenalkan dalam konsep New Public Management beorientasi pada kinerja dan hasil. Salah satu bentuk adopsi konsep New Public Management dalam sektor publik di Indonesia adalah dengan dibentuknya Badan Layanan Umum dengan jargon yang dikembangkan yakni 'Let the managers manage, make the managers manage" yang memiliki arti memberikan kesempatan kepada manager (pimpinan satuan kerja) mengelola jasa-jasa pemerintah (pendidikan, rumah sakit, dan sebagainya) dengan menggunakan anggaran dengan cara paling efektif dan efisien serta memastikan jasa-jasa yang dikelola oleh pimpinan satuan kerja tersebut dilakukan secara efisien dan efektif sehingga menghasilkan kinerja (Waluyo 2011). Melalui adaptasi konsep New Public Management tersebut, diharapkan Badan Layanan Umum dapat menjadi contoh konkrit penerapan manajemen keuangan berbasis pada hasil dan kinerja (Sulanjari 2016).

Badan Layanan Umum merupakan instansi pemerintahyang dibentuk untuk memberikan pelayanan kepada masyarakat berupa penyediaan barang dan/atau jasa yang dijual dengan tidak mengutamakan mencari keuntungan dan dalam pelaksanaan kegiatannya didasarkan pada prinsip efisiensi dan produktivitas (UU Nomor 1 Tahun 2004). Salah satu contoh Badan Layanan Umum di Indonesia adalah Perguruan Tinggi yang bergerak sebagai penyedia layanan barang dan/atau jasa di bidang pendidikan. Perguruan Tinggi memiliki peran dalam menyediakan lulusan, yang tidak hanya dilihat dari segi kuantitas tetapi juga berkualitas dan disiplin tinggi, dapat berperan sebagai dinamisator, innovator, motivator serta penggerak pembangunan dan memproduksi sumber daya manusia yang berkualitas dalam berbagai tingkatan dan keahlian (Effendi 2003). Perguruan Tinggi di Indonesia dikategorikan menjadi 3 (tiga) berdasarkan UU Nomor 12 Tahun 2012 diantaranya, Perguruan Tinggi Negeri Badan Hukum, Perguruan Tinggi Negeri Badan Layanan Umum, serta Perguruan Tinggi Negeri berbentuk Satuan Kerja. Perguruan Tinggi Negeri merupakan lembaga sosial yang bertugas mengembangkan ilmu pengetahuan dan teknologi (Amirya, Djamhuri, \& Ludigdo 2012). Terdapat 2 (dua) Perguruan Tinggi Negeri di Provinsi Bali yang berstatus Perguruan Tinggi Negeri Badan Layanan Umum yakni, Universitas Udayana serta Universitas Pendidikan Ganesha. Kedua Perguruan Tinggi tersebut selanjutnya menerapkan PK-BLU (Pengelolaan 
Keuangan Badan Layanan Umum) yang merupakan pengelolaan keuangan yang prinsipnya memberikan fleksibilitas menerapkan praktek-praktek bisnis yang sehat sehingga dapat meningkatkan pelayanan terhadap masyarakat dengan tujuan umum memajukan kesejahteraan dan mencerdaskan kehidupan bangsa, sebagai pengecualian dari ketentuan pengelolaan keuangan negara pada umumnya.

Laporan Keuangan merupakan salah satu persyaratan penting bagi Badan Layanan Umum dalam menerapkan PK-BLU. Penyusunan laporan keuangan adalah bentuk transparansi dengan syarat pendukungnya adalah adanya akuntabilitas yang berupa keterbukaan (openness) pemerintah atas aktivitas pengelolaan sumber daya publik (Alit et al., 2015). Akuntabilitas dan transparansi pengelolaan keuangan negara menjadi hal yang penting bagi sektor publik (Tambingon et al., 2018). Laporan keuangan harus disusun secara cermat dan terbebas dari bias dan dapat diinterpretasikan oleh para pengguna yang memiliki kepentingan (interested party) dalam pemahaman yang sama (Saputra et al., 2017).

Hingga tahun 2015, Badan Layanan Umum memiliki posisi ganda terkait pelaporan keuangannya yakni, sebagai entitas pelaporan dan entitas akuntansi (Kawenas, et al., 2018). Posisi ganda Badan Layanan Umum inilah yang menyebabkan Badan Layanan Umum wajib untuk menyajikan 2 (dua) jenis laporan keuangan yaitu Laporan Keuangan yang mengacu pada Standar Akuntansi Keuangan dan Standar Akuntansi Pemerintahan. Dualisme pelaporan keuangan Badan Layanan Umum di Indonesia disebabkan oleh basis akuntansi kas menuju akrual yang digunakan dalam sistem akuntansi pemerintahan Indonesia kala itu. Perubahan besar yang terjadi dalam penggunaan basis akuntansi akrual di negara-negara OECD menjadi salah satu ciri politik manajemen keuangan modern yang mendorong Indonesia untuk menerapkan basis akuntansi akrual sebagai basis akuntansi dalam sistem akuntansi pemerintahan. Basis akuntansi akrual adalah basis akuntansi yang mengakui ransaksi pada saat terjadi bukan pada saat kas diterima ataupun dibayarkan (Shanti 2018). Basis akuntansi akrual dirasa lebih relevan, dapat diandalkan, dan dibandingkan untuk kepentingan sektor publik (Karunia, et al., 2019). Sebagai ciri khas manajemen keuangan modern, basis akuntansi akrual menjadi hal yang penting dalam mencapai transparansi dan akuntabilitas yang lebih besar bagi pelaporan keuangan pemerintahan di seluruh dunia (Indriani et al. 2018). Selain dibentuknya Badan Layanan Umum, penggunaan basis akuntansi akrual juga menjadi salah satu bentuk implementasi konsep New Public Management (Safkaur et al. 2019). Penggunaan basis akuntansi akrual dalam pemerintahan Indonesia dilakukan secara bertahap yang dimulai dengan pengenalan basis akuntansi kas menuju akrual sebagai bentuk adaptasi pemerintahan Indonesia sebelum menggunakan basis akuntansi akrual secara penuh pada tahun 2015 (Rachmawati et al., 2018).

Berakhirnya penerapan basis akuntansi kas menuju akrual di Indonesia menyebabkan PMK Nomor 76/PMK.05/2008 tentang Pedoman Akuntansi dan Pelaporan Keuangan Badan Layanan Umum tidak diberlakukan lagi mengingat basis akuntansi yang digunakan berdasarkan ketentuan tersebut adalah basis akuntansi kas menuju akrual. Hal ini 
menyebabkan beberapa Badan Layanan Umum mengacu pada Peraturan Pemerintah Nomor 71 Tahun 2010 tentang Standar Akuntansi Pemerintahan. Namun, dalam Peraturan Pemerintah Nomor 71 Tahun 2010, belum adanya pedoman yang mengatur mengenai pelaporan keuangan Badan Layanan Umum secara mengkhusus. Pelaporan Keuangan Badan Layanan Umum dalam Peraturan Pemerintah Nomor 71 Tahun 2010 hanya disiratkan sedikit dalam PSAP Nomor 11 mengenai Laporan Konsolidasian. Menjawab terkait kebutuhan pedoman dalam pelaporan keuangan Badan Layanan Umum, Menteri Keuangan menerbitkan Peraturan Menteri Keuangan Nomor 217/PMK.05/2015 tentang Pernyataan Standar Akuntansi Pemerintahan Nomor 13 tentang Penyajian Laporan Keuangan Badan Layanan umum pada tanggal 2 Desember 2015 yang mulai diterapkan dalam penyusunan laporan keuangan Badan Layanan Umum untuk tahun anggaran 2016. Menteri Keuangan selanjutnya menerbitkan PMK Nomor 220/PMK.05/2016 yang mengatur tentang Sistem Akuntansi dan Pelaporan Keuangan Badan Layanan Umum. Implementasi terhadap kedua ketentuan baru dalam pelaporan keuangan Badan Layanan Umum tersebut harus mengalami penundaan yang awalnya dimulai pada tahun anggaran 2016, menjadi tahun anggaran 2017 berdasarkan ketentuan PMK Nomor 42/PMK.05/2017 tentang Perubahan Atas PMK Nomor 220/PMK.05/2016 tentang Sistem Akuntansi dan Pelaporan Keuangan Badan Layanan Umum.

Penerapan PSAP Nomor 13 dalam pelaporan keuangan Badan Layanan Umum mengalami perkembangan yang signifikan terlihat dari beberapa penelitian yang sudah membuktikan bahwa penerapan PSAP Nomor 13 sudah berjalan meskipun mengalami penundaan. Kawenas et al. (2018), membuktikan dalam penelitiannya bahwa RSUP Prof. Dr. R. D. Kandou Manado belum menerapkan PSAP Nomor 13 secara keseluruhan, khususnya dalam pengakuan pendapatan atas kerjasama operasional (KSO). Wibowo dan Varikha (2018) membuktikan dalam penelitiannya bahwa PKN STAN sudah berhasil menerapkan PSAP Nomor 13 dalam pelaporan keuangan tahun 2017 meskipun peneliti menyarankan masih diperlukan adanya pelatihan penggunaan aplikasi SAIBA. Florentina et al., (2019) juga membuktikan bahwa Laporan Keuangan Rumah Sakit Umum Daerah (RSUD) Harapan Insan Sendawar sebagian besar telah sesuai dengan PSAP Nomor 13.

Universitas Pendidan Ganesha sudah mengacu pada PSAP Nomor 13 dan PMK Nomor 220/PMK.05/2016 dalam pelaporan keuangannya sejak tahun anggaran 2017. Hal ini menunjukkan bahwa Universitas Pendidikan Ganesha sudah mengacu pada kedua ketentuan baru tersebut dalam pelaporan keuangannya. Keberhasilan Universitas Pendidikan Ganesha dalam menerapkan kedua ketentuan tersebut menjadi hal yang menarik untuk diteliti karena meskipun sudah menerapkan kedua ketentuan tersebut, apakah Universitas Pendidikan Ganesha tidak mengalami kendala-kendala yang serius dalam menerapkan PSAP Nomor 13 dan apakah laporan keuangan yang disajikan sudah sesuai dengan ketentuan dalam PSAP Nomor 13 tentang Penyajian Laporan Keuangan Badan Layanan Umum. 


\section{METODE PENELITIAN}

Penelitian ini menggunakan metode kualitatif dengan pendekatan yang digunakan adalah pendekatan studi kasus. Data dalam penelitian diperolehmelalui studi dokumentasi, observasi, serta in-depth interview. Lokasi Penelitian dilakukan di Universitas Pendidikan Ganesha dengan pertimbangan Universitas Pendidikan Ganesha sudah menerapkan PSAP Nomor 13 sejak tahun 2017. Objek Penelitian adalah variabel atau apa yang menjadi titik perhatian suatu penelitian. Dalam penelitian ini, yang menjadi objek penelitian adalah penerapan dan evaluasi PSAP No. 13 dalam penyajian laporan keuangan Badan Layanan Umum Universitas Pendidikan Ganesha.

Jenis data yang digunakan dalam penelitian ini adalah data kualitatif dan data kuantitatif. Data kualitatif dalam penelitian ini meliputi Perkembangan Universitas Pendidikan Ganesha serta Struktur Organisasi Universitas Pendidikan Ganesha. Data kuantitatif yang digunakan dalam penelitian ini adalah laporan keuangan Universitas Pendidikan Ganesha Tahun Anggaran 2018. Data primer diperoleh peneliti melalui in-depth interview dengan Kepala Sub Bagian Akuntansi dan Pelaporan Biro umum dan Keuangan Universitas Pendidikan Ganesha serta Staff Akuntansi dan Pelaporan Biro Umum dan Keuangan Universitas Pendidikan Ganesha. Dari hasil in-depth interview tersebut diharapkan dapat memperoleh informasi mengenai penyajian laporan keuangan Universitas Pendidikan Ganesha serta kendala yang dihadapi dalam menyajikan informasi keuangan. Data sekunder yang diperoleh dalam penelitian ini adalah laporan keuangan Universitas Pendidikan Ganesha Tahun Anggaran2018.

Analisis data yang digunakan dalam penelitian ini menggunakan tahapan-tahapan analisis data kualitatif model Miles dan Huberman (1992) yang meliputi pengumpulan data, mereduksi data, penyajian data dalam bentuk naratif yang dikutip dari interview transcription, dan tahap selanjutnya adalah membuat kesimpulan. Untuk membuktikan sejauh mana keberhasilan penelitian dapat dipercaya, pengujian keabsahan data perlu dilakukan. Pengujian keabsahan data dalam penelitian ini dilakukan dengan cara meningkatkan ketekunan dalam penelitian, triangulasi data, serta menggunakan bahan referensi pendukung untuk membuktikan data yang telahditemukan.

\section{HASIL DAN PEMBAHASAN}

Universitas Pendidikan Ganesha ditetapkan menjadi Badan Layanan Umum sejak tahun 2015 berdasarkan Keputusan Menteri Keuangan Nomor 505/KMK.05/2015 yang secara langsung membuat Universitas Pendidikan Ganesha harus mengacu pada PSAP Nomor 13 tentang Penyajian Laporan Keuangan Badan Layanan Umum dan PMK Nomor 220/PMK.05/2016 dalam penyusunan laporan keuangan setiap tahunnya. Data yang dikumpulkan melalui wawancara, memberikan informasi bahwa Universitas Pendidikan Ganesha sudah menerapkan PSAP Nomor 13 sejak tahun 2017. Sebelum menerapkan PSAP Nomor 13dalam pelaporan keuangannya, Universitas Pendidikan Ganesha mengacu pada PMK Nomor 76/PMK.05/2008. Perbedaan yang dirasakan pada kedua ketentuan tersebut terletak pada 
komponen laporan keuangan yang disajikan. Komponen laporan keuangan sesuai PMK Nomor 76/PMK.05/2008 terdiri dari: Laporan Realisasi Anggaran dan/atau Laporan Operasional, Neraca, Laporan Arus Kas, dan Catatan Atas Laporan Keuangan sedangkan berdasarkan PSAP Nomor 13 komponen laporan keuangan yang harus disajikan meliputi: Laporan Realisasi Anggaran (LRA), Laporan Perubahan Saldo Anggaran Lebih (LPSAL), Laporan Arus Kas, Laporan Operasional (LO), Neraca, Laporan Perubahan Ekuitas (LPE), dan Catatan Atas Laporan Keuangan (CaLK).

Penyajian Laporan Keuangan Universitas Pendidikan Ganesha sudah mengacu pada PSAP Nomor 13. Hal ini dapat dilihat dari penyajian Laporan Realisasi Anggaran (LRA), Laporan Perubahan Saldo Anggaran Lebih (LPSAL), Neraca, Laporan Operasional (LO), Laporan Arus Kas, Laporan Perubahan Ekuitas (LPE), serta Catatan atas Laoran Keuangan (CaLK) sesuai dengan komponen penyajian laporan keuangan yang diatur dalam PSAP Nomor 13. Secara garis besar, Laporan Realisasi Anggaran (LRA) Universitas Pendidikan Ganesha Tahun Anggaran menyajikan pos-pos seperti Pendapatan-LRA, Belanja, Surplus/Defisit LRA, serta Sisa lebih/kurang pembiayaan anggaran (SiLPA/SiKPA). Tidak ada pos penerimaan pembiayaan, pengeluaran pembiayaan, serta pembiayaan neto dalam laporan keuangan yang disajikan dikarenakan saldo pembiayaan Universitas Pendidikan Ganesha untuk Tahun Anggaran 2018 sebesar Rp 0. Salah satu ketentuan Laporan Realisasi Anggaran dalam PSAP Nomor 13 yakni paragraf 26 mengenai pengakuan pendapatan dari Kerja Sama Operasional mengalami penundaan berdasarkan Surat Keputusan Menteri Keuangan Nomor S469/MK.5/2018. Laporan Perubahan Saldo Anggaran Lebih (LPSAL) Universitas Pendidikan Ganesha Tahun Anggaran 2018 menyajikan pos Saldo Anggaran Lebih Awal, Penggunaan Saldo Anggaran Lebih, Sisa Lebih/Kurang Pembiayaan Anggaran tahun berjalan, Koreksi Kesalahan Pembukuan tahun sebelumnya, Lain-Lain, dan Saldo Anggaran Lebih Akhir yang sesuai dengan ketentuan pos-pos yang disajikan dalam PSAP Nomor13. Neraca Universitas Pendidikan Ganesha Tahun Anggaran 2018 menyajikan 7 (tujuh) pos yakni; Kas dan Setara Kas, Persediaan, Investasi Jangka Pendek, Aset Tetap, Aset Lainnya, Kewajiban Jangka Pendek, dan Ekuitas. Pada tahun 2018, Universitas Pendidikan Ganesha tidak memiliki piutang yang timbul akibat kegiatan BLU serta tidak adanya investasi jangka panjang selama periode tersebut. Pos-pos yang disajikan dalam Laporan Operasional (LO) Universitas Pendidikan Ganesha Tahun Anggaran 2018 sudah sesuai dengan ketentuan dalam PSAP Nomor 13 hanya saja, salah satu ketentuan Laporan Operasional yakni paragrapf 82 mengenai pengakuan pendapatan dari Kerja Sama Operasional mengalami penundaan berdasarkan Surat Keputusan Menteri Keuangan Nomor S-469/MK.5/2018.

PSAP Nomor 13 mengatur arus masuk dan keluar kas yang disajikan dalam Laporan Arus Kas diklasifikasikan berdasarkan aktivitas operasi, investasi, pendanaan, dan transitoris. Laporan Arus Kas Universitas Pendidikan Ganesha Tahun Anggaran 2018 menyajikan informasi arus masuk dan keluar kas berdasarkan aktivitas operasi, investasi, dan transitoris. Hal ini disebabkan pada tahun 2018, saldo pada arus masuk dan keluar kas dari 
aktivitas pendanaan sebesar Rp 0 atau bisa dikatakan tidak terjadinya aktivitas pendanaan pada periode tersebut. Laporan Perubahan Ekuitas Universitas Pendidikan Ganesha Tahun Anggaran 2018 menyajikan pos Ekuitas Awal, Surplus/Defisit-LO, Koreksi-Koreksi Langsung yang Menambah/Mengurangi ekuitas, serta Ekuitas Akhir. Pos-pos yang disajikan sudah sesuai dengan ketentuan dalam PSAP Nomor13. Berdasarkan hasil analisa, maka penyajian laporan keuangan Universitas Pendidikan Ganesha sudah sesuai dengan ketentuan dalam PSAP Nomor 13.

Keberhasilan penerapan PSAP Nomor 13 dalam pelaporan keuangan Universitas Pendidikan Ganesha tidak terlepas dari kendala yang dihadapi. Berdasarkan informasi yang diperoleh melalui wawancara, Universitas Pendidikan Ganesha memiliki beberapa kendala dalam menyajikan informasi laporan keuangan. Kendala tersebut terletak pada penyampaian informasi keuangan serta pemahaman sumber daya manusia Universitas Pendidikan Ganesha mengenai basis akuntansi akrual secara penuh. Bagian akuntansi dan pelaporan Universitas Pendidikan Ganesha terkadang memiliki permasalahan dalam mengkonfirmasi atas transaksi yang terjadi misalkan, ketika bagian akuntansi dan pelaporan ingin mengonfirmasi pembelian map yang dilakukan oleh BKK, staff yang melakukan pembelian tersebut sulit untuk menjabarkan kembali transaksi yang terjadi sehingga diperlukannya tracing ulang oleh bagian akuntansi dan pelaporan. Pemahaman sumber daya manusia Universitas Pendidikan Ganesha terkait dengan basis akuntansi akrual juga dirasa kurang, hal ini yang menyebabkan Universitas Pendidikan Ganesha belum menerapkan basis akrual secara penuh. Terlepas dari kendala yang dihadapi oleh Universitas Pendidikan Ganesha dalam pemahaman mengenai PSAP Nomor 13 maupun penggunaan basis akrual secara penuh, Universitas Pendidikan Ganesha sudah berhasil menerapkan PSAP Nomor 13 sejak tahun 2017. Keberhasilan ini tentu saja merupakan hasil kerjasama antara Sumber Daya Manusia yang terdapat di Universitas Pendidikan Ganesha untuk mencoba memahami, mempelajari, dan mengimplementasikannya sebaik mungkin mengingat penerapan PSAP Nomor 13 merupakan bentuk kepatuhan Universitas Pendidikan Ganesha terhadap Pemerintah Indonesia.

\section{SIMPULAN}

Hasil penelitian dalam mengevaluasi penerapan PSAP Nomor 13 dalam penyajian laporan keuangan Universitas Pendidikan Ganesha menyimpulkan bahwa laporan keuangan Universitas Pendidikan Ganesha sudah sesuai dengan ketentuan dalam PSAP Nomor 13 meskipun terdapat beberapa pos yang tidak disajikan dalam Laporan Realisasi Anggaran dan Laporan Arus Kas serta adanya penundaan penerapan paragraf 26 dan 82 dalam PSAP Nomor 13 berdasarkan Surat Keputusan Menteri Keuangan Nomor S469/MK.5/2018. Kendala dalam penyampaian informasi yang akan disajikan dalam laporan keuangan serta pemahaman sumber daya manusia yang kurang dalam penerapan basis akrual secara penuh tidak menjadi penghalang untuk menerapkan PSAP Nomor 13.

Berdasarkan hasil penelitian, maka peneliti dapat memberi saran perlunya sumber daya manusia yang memiliki keahlian di bidang akuntansi 
khususnya akuntansi sektor publik agar penyampaian informasi yang akan disajikan dalam laporan keuangan dapat efisien dan efektif serta mempertimbangkan untuk melakukan sistem sentralisasi dalam pengelolaan keuangan untuk akun-akun yang krusial sehingga pengendalian informasi keuangan berada pada Rektorat Universitas Pendidikan Ganesha.

\section{REFERENSI}

Alamsyah, A. (2016). Perkembangan Paradigma Administrasi Publik ( New Public Administration, New Public Management dan New Public Service ). Jurnal Politik Profetik, 04(2), 172-199.

Amirya, M., Djamhuri, A., \& Ludigdo, U. (2012). Pengembangan Sistem Anggaran dan Akuntansi Badan Layanan umum Universitas Brawijaya: Perspektif Institusionalis. Jurnal Akuntansi Multiparadigma, 3(3), 334-501.

Apriliani Alit, N. K., Sujana, E., \& Yuniarta Adi, G. (2015). Pengaruh Penyajian Laporan Keuangan, Karakteristik Kualitatif, Dan Aksesibilitas Terhadap Transparansi Laporan Keuangan Pemerintah Daerah (Studi Empiris Pada Satuan Kerja Perangkat Daerah Kabupaten Klungkung). E-Journal S1 Ak Universitas Pendidikan Ganesha, 3(1).

Budi Waluyo. (2014). Analisis Permasalahan Pada Implementasi Pola Pengelolaan. Jurnal Infoartha, 3, 27-38.

CHOI, J.-W. (2016). New Public Management or Mismanagement? The Case of Public Service Agency of Indonesia. Journal of Government and Politics, 7(1), 104. https://doi.org/10.18196/jgp.2016.0024

Diana, S. R., \& Limakrisna, N. (2018). Strategic Decision Policy of Public Service Agency as Government Institution: Analysis of Government Financial Performance. International Journal of Economics and Financial Issues, 8(6), 115- 118.

Firdausi, R. Y., \& Pujiningsih, S. (2018). Pemaknaan Perubahan Puskesmas X Menuju Badan Layanan Umum Daerah (Blud) Dalam Aspek Layanan Dan Akuntansi. Jurnal Akuntansi Aktual, 5(1), 92-107. https://doi.org/10.17977/um004v5i12018p092

Hajar, B. (2015). Bureaucracy and Governance in Indonesia: Study on West Sulawesi Province. Procedia Economics and Finance, 23, 223-227. https://doi.org/10.1016/s2212-5671(15)00348-2

Indriasih, D. (2014). The Effect of Government Apparatus Competence and the Effectiveness of Government Internal Control Toward the Quality of Financial Reporting in Local Government. Research Journal of Finance and Accounting, 5(20), 38-47.

Indriani, M., Mulyany, R., Nadirsyah, N., \& Munandar, W. (2018). Readiness of Local Government in the Implementation of Accrual Accounting: The Case of Local Government in Aceh, Indonesia. Jurnal of Accounting and Business Dynamics, 5(1), 87-100. https://doi.org/10.24815/jdab.v5i1.8441

Karunia, A. P., Payamta, P., \& Sutaryo, S. (2019). The Implementation of Accrual- based Accounting in Indonesian Government: Has Local Government Financial Statement Quality Improved? Journal of Accounting and Investment, 20(2), 26-43. https://doi.org/10.18196/jai.2002115. 
Kawenas, R. I., Kalangi, L., \& Lambey, L. (2018). Analisis Penerapan PSAP Nomor 13 Tentang Penyajian Laporan Keuangan Badan Layanan Umum Pada RSUP Prof . Dr . R. D . Kandou Manado. Jurnal Riset Akuntansi Dan Auditing Goodwill, 9(1),1-11.

Keputusan Menteri Keuangan Nomor 441/KMK.05/2011 tentang Penetapan Universitas Udayana sebagai Instansi Pemerintah yang Menerapkan Pengelolaan Keuangan Badan Layanan Umum.

Keputusan Menteri Keuangan Nomor 505/KMK.05/2015 tentang Penetapan Universitas Pendidikan Ganesha sebagai Instansi Pemerintah yang Menerapkan Pengelolaan Keuangan Badan Layanan Umum.

Klenk, T., \& Reiter, R. (2019). Post-New Public Management: reform ideas and their application in the field of social services. International Review of Administrative Sciences, 85(1), 3-10. https://doi.org/10.1177/0020852318810883

Mahmudi, M. (2003). New Public Management (NPM): Pendekatan Baru Manajemen Sektor Publik. Sinergi, 6(1), 69-76. https:// doi.org/10.20885/ sinergi.vol6.iss1.art5

Mentu, E. P., \& Sondakh, J. (2016). Penyajian Laporan Keuangan Daerah Sesuai Peraturan Pemerintah No.71 Tahun 2010 Tentang Standar Akuntansi Pemerintahan Pada Dinas Pendapatan Daerah Dan Dinas Sosial Prov. Sulut. Jurnal Riset Ekonomi, Manajemen, Bisnis Dan Akuntansi, 4(1), 13921399.

Muzarrafah, Majid, J., \& Anwar, P. H. (2019). Disclaimer Opinion: Pengungkapan Laporan Keuangan Pemerintah Daerah

(Studi Pada Pemda Kabupaten Jeneponto). Jurnal Ilmiah Akunansi Peradaban, 5(1), 125-161. https:// doi.org/10.1017/CBO9781107415324.004

Pahala, I., Sudarma, M., Sutrisno, \& Rosidi. (2016). Financial Accountability on Public Service Agency ( BLU ): Phenomenological study at the State University of Jakarta. Review of Integrative Business and Economics Research, 5(2), 11-27.

Pratama, A. B. (2020). The landscape of public service innovation in Indonesia. Innovation $\mathcal{E}$ Management Review, 17(1), 25-40. https://doi.org/10.1108/inmr-11-2018-0080

Purnomo, A. S. (2018). Citizen-Oriented Service Delivery and Innovation in the Passport Office in Indonesia. Jurnal Ekonomi Dan Kebijakan Publik, 9(1), 15-27. https:// doi.org/10.22212/jekp.v9i1.723

Rachmawati, Djamhuri, A., \& Andayani, W. (2018). Studi Fenomenologi Atas Implementasi Akuntansi Berbasis Akrual pada Badan Layanan Umum Daerah RSUD Dr. Saiful Anwar Malang. Jurnal Akuntansi Aktual, 5(2), 121- 128.

Safkaur, O., Afiah, N. N., Poulus, S., \& Dahlan, M. (2019). The Effect of Quality Financial Reporting on Good Governance. International Journal of Economics and Financial Issues, 9(3), 277-286. https://doi.org/10.32479/ijefi.8047

Saputra, M. D., Sondakh, J. J., \& Runtu, T. (2017). Analisis Penyajian Laporan Keuangan Berdasarkan Penerapan Standar Akuntansi Keuangan Entitas Tanpa Akuntabilitas Publik Pada Pt. Fortuna Inti Alam. Jurnal Riset 
Akuntansi Going Concern, 12(01), 1-9.

Shanti, Y. K. (2018). Analisis Penerapan Basis Akrual Atas Standar Akuntansi Pemerintah No 71 Dan Dampaknya Pada Penyajian Laporan Keuangan (Studi Kasus Pada Satuan Kerja Perangkat Daerah Kecamatan Ciputat Timur). Jurnal Akuntansi Berkelanjutan Indonesia, 1 (1), 43. https:/ / doi.org/10.32493/jabi.v1i1.y2018.p43-60

Sulanjari, L. (2016). Accounting Standard Implementation of Public Service Agency From Luder Contingency Theory. Jurnal Bisnis Dan Ekonomi, 14(2), 143-150.

Tambingon, H. N., Yadiati, W., \& Kewo, C. L. (2018). Determinant Factors Influencing the Quality of Financial Reporting Local Government in Indonesia. International Journal of Economics and Financial Issues, 8(2), 262268.

Undang-Undang Nomor 17 Tahun 2003 tentang Keuangan Negara.

Undang-Undang Nomor 1 Tahun 2004 tentang Perbendaharaan

Negara.

Undang-Undang Nomor 23 Tahun 2005 tentang Pengelolaan Keuangan Badan Layanan Umum.

https://doi.org/10.32400/gc.12.01.17209.2017

Undang-Undang Nomor 12 Tahun 2012 tentang Pendidikan Tinggi.

Waluyo, I. (2011). Badan Layanan Umum Sebuah Pola Baru Dalam Pengelolaan Keuangan Di Satuan Kerja Pemerintah. Jurnal Pendidikan Akuntansi Indonesia, 9(2), 1-15. https://doi.org/10.21831/jpai.v9i2.962

Waluyo, Budi. (2016). Agencification in Indonesian Public Service: Cases of Higher Education. International Research Society for Public Management (IRSPM) Conference. City University of Hongkong, China.

Wibowo, Puji., \& Varikha, Naela. (2018). Transformasi Pelaporan Keuangan Basis Akrual pada Politehnik Keuangan Negara STAN: Sudahkah Tuntas?. Jurnal Substansi, 2(1).

Wicaksana, F. G., Trihatmoko, R. A., Suhardjanto, D., \& Murtini, H. (2019). The Regulation on Village Governance in Indonesia: Efficient Contracting in Agency Theory. Journal of Public Administration and Governance, 9(2), 110. https://doi.org/10.5296/jpag.v9i2.14812

Yunilistyowati, Florentina., Konde, Yunus Tete., \& Sari, Dhina Mustika. (2019). Analisis Pelaporan Keuangan pada Rumah Sakit Umum Daerah (RSUD) Harapan Insan Sendawar yang Berstatus Badan Layanan Umum di Kutai Barat. Jurnal Ilmu Akuntansi Mulawarman, 4 (1). 